$11-2021$

\title{
Antecedents and Outcomes of Duty Orientation Among Salespeople
}

James DeConinck

Western Carolina University, North Carolina, U.S.

Drew Carnes

Western Carolina University, North Carolina, U.S.

Mary Beth DeConinck

Western Carolina University, North Carolina, U.S.

Follow this and additional works at: https://digitalcommons.newhaven.edu/americanbusinessreview

Part of the Marketing Commons

\section{Recommended Citation}

DeConinck, James; Carnes, Drew; and DeConinck, Mary Beth (2021) "Antecedents and Outcomes of Duty Orientation Among Salespeople," American Business Review. Vol. 24 : No. 2 , Article 5.

DOI: https://doi.org/10.37625/abr.24.2.100-114

Available at: https://digitalcommons.newhaven.edu/americanbusinessreview/vol24/iss2/5 
Antecedents and Outcomes of Duty Orientation Among Salespeople
American Business Review Nov. 2021, Vol.24(2) 100 - 114 (c) The Authors 2021, CC BY-NC ISSN: 2689-8810 (Online) ISSN: 0743-2348 (Print)

\title{
James DeConinck ${ }^{\mathrm{a}}$, Drew Carnes ${ }^{\mathrm{a}}$, and Mary Beth DeConinck ${ }^{\mathrm{a}}$
}

https://doi.org/10.37625/abr.24.2.100-114

\begin{abstract}
This study analyzed the relationship among ethical leadership, duty orientation, perceived organizational support (PSS), organizational citizenship behaviors (OCBs) and job performance among a sample of 45 sales managers and 203 salespeople. Duty orientation and perceived organizational support were found to mediate the relationship between ethical leadership and performance outcomes. Ethical leadership was a direct predictor of OCBs but not job performance. This study shows the importance of analyzing ethical leadership, duty orientation, and PSS and their relationship with OCBs and job performance in the salesforce.
\end{abstract}

\section{KEYWORDS}

Ethical Leadership, Duty Orientation, Perceived Supervisor Support, Organizational Citizenship Behaviors, Performance

\section{INTRODUCTION}

Because of the highly publicized ethical scandals involving top executives, ethical leadership has become the focus of many studies (Bedi et al., 2016; Ng and Feldman, 2015). Ethical leadership is defined as "the demonstration of normatively appropriate conduct through personal actions and interpersonal relationships, and the promotion of such conduct to followers through two-way communication, reinforcement, and decision making" (Brown et al., 2005, p. 120). The costs of unethical leadership in corporations has been estimated to be in the billions of dollars (Detert et al., 2007). Ethical leadership is important for all parts of an organization. However, it is especially important for the salesforce for several reasons (DeConinck, 2015). First, salespeople encounter potential ethical dilemmas when trying to meet their quota while providing long-term customer satisfaction. They may feel pressure to behave unethically to make quota. Second, because salespeople frequently operate without direct supervision, they encounter more opportunities to engage in unethical behavior (Babin et al., 2000). Third, sales managers, who are viewed as ethical leaders, will influence their salespersons' behavior by instituting core values and emphasizing their importance in developing superior customer value leading to increased sales (Schwepker and Ingram, 2016). Fourth, employing an ethical salesforce is vital for an organization to attract and retain customers (Ingram et al., 2007).

While prior research has provided important insights into how ethical leadership influences employees' job attitudes and behaviors (Bedi et al., 2016; Brown and Mitchell, 2010; Brown and Treviño, 2006), recent research has shown that ethical leadership influences extra-role performance and intra-role performance indirectly through two other variables, duty orientation and perceived organizational support (POS) (Eva et al., 2020; Hannah et al., 2014). Duty orientation is "an individual's volitional orientation to loyally serve and faithfully support other members of the group, to strive and

a Western Carolina University, North Carolina, U.S.

Corresponding Author:

J. DeConinck (deconinck@wcu.edu) 
sacrifice to accomplish the tasks and missions of the group, and to honor its codes and principles" (Hannah et al., 2014, p. 234). Hannah and colleagues (2014) suggested that people who are high in duty orientation will make ethical judgments based on their obligation (duty) to the group and behave consistently regarding those duties. In their study involving multiple samples of employees, they reported that ethical leadership influences duty orientation.

They encouraged future research investigating the relationship among ethical leadership, duty orientation, and performance measures. However, to date only one study (Eva et al., 2020) has attempted to analyze the relationship among these variables and that study was conducted with Chinese public sector employees.

This study makes an important contribution to the current literature by examining the indirect influence of ethical leadership through duty orientation on salespersons' intra-role performance and extra-role performance. Understanding the relationship among ethical leadership, duty orientation, perceived supervisor support (PSS) and performance is particularly important in professional selling. The nature of a salesperson's job is different from other organizational employees. Unlike other employees, most salespeople are compensated through an incentive system and are under pressure to meet their quota. Given their boundary role, salespeople often are responsible for acquiring information about customers while creating and maintaining customer loyalty leading to a long-term relationship (Blocker et al., 2012). Thus, understanding variables related directly or indirectly to performance is very important.

The second important contribution of this study is examining how ethical leadership influences PSS. PSS involves the level to which employees perceive their supervisor cares about their well-being (Rhoades and Eisenberger, 2002). While most research has investigated perceived organizational support (POS), this study examines the role of the sales manager (PSS). Salespeople go through the excitement of making a sale to the disappointment of not making a sale. They need to believe their sales manager supports them during “down" times. Salespersons' assessment of their sales manager's ethical leadership behavior should increase their PSS. Ethical leaders emphasize honesty and integrity and care about their subordinates while being role models who employees view as having their bests interests in mind (Brown and Treviño, 2006). Supportive leaders care about their subordinates' well-being and opinions, strongly consider their goals and values, and appreciate their contributions. These traits are similar to the ones possessed by ethical leaders. Support from the sales manager will enable salespeople to meet their goals better (DeConinck and Johnson, 2009). The uniqueness of a salesperson's job (e.g., given the number of times they encounter rejection) (Boichuk et al., 2014) indicates the need to comprehend how ethical leadership influences PSS and indirectly performance outcomes.

Support of the sales manager is important in achieving sales performance (MacKenzie et al., 2001; Peesker et al., 2019). Based on social exchange theory (Blau, 1964) and the norm of reciprocity (Gouldner, 1960), employees who perceive support from their supervisor will reciprocate that behavior through increased effort and performance. Eva et al. (2020) reported that POS mediated the relationship between duty orientation and performance variables. These authors did not, however, analyze if PSS influences duty orientation. Given the important role of the sales manager in a professional selling context, a need exists to investigate how PSS influences duty orientation and intrarole performance and extra-role performance.

The purpose of this study is to examine the relationship among ethical leadership, duty orientation, PSS, intra-role performance and extra-role performance. Specifically, this study expands on prior research by examining how duty orientation mediates the relationship between ethical leadership, PSS, and performance outcomes. A hypothesized model was developed based on the literature review. Support for model appears in the literature review below. 


\section{LITERATURE REVIEW}

\section{DUTY ORIENTATION}

According to Hannah et al. (2014), duty orientation consists of three elements of duties: accomplish the tasks and mission of the organization by utilizing additional effort and sacrifice (duty to mission); faithfully serve and support team members (duty to members); and maintain the values and honor the team's codes according to the norms established by the group (duty of codes). Employees high in duty orientation strive for excellent performance because of a desire to help the organization achieve success (Moon, 2001). They will feel guilty when unable to assist coworkers in need (Grant and Wrzesniewski, 2010) and will participate in behaviors that benefit the organization, although they may not benefit from that behavior (Moon et al., 2008).

\section{ETHICAL LEADERSHIP}

Ethical leadership is based on a social learning perspective (Bandura, 1977; 1986). According to social learning theory, people learn appropriate behavior by observing others (role modeling) and how these people are either rewarded or punished for ethical or unethical behavior. Acting as a role model, leaders can encourage ethical behavior by showing the type of behavior they want to encourage and reward (Brown and Treviño, 2006). Managers can influence subordinates' behavior directly through acting as role models (Treviño et al., 2000). Ethical behavior is increased when employees see their manager behaving ethically. However, the opposite situation will occur when employees see their manager behaving unethically. Thus, both ethical and unethical leaders can be viewed as role models (Brown and Treviño, 2006).

Ethical leadership is comprised of two components: the moral person and the moral manager. The moral person is viewed as possessing characteristics such as caring, honesty, trustworthiness, integrity, and fairness. The moral manager proactively attempts to impact followers' behavior by establishing ethical guidelines wherein ethical behavior is rewarded and unethical behavior is punished (Brown and Treviño, 2006).

Ethical leadership is defined by four essential behaviors (Brown et al., 2005; Brown and Treviño, 2006). First, ethical leaders establish distinct guidelines for ethical behavior. Second, they participate in discussions with subordinates regarding ethical issues. Third, ethical leaders, through their behavior, become role models for subordinates. Fourth, they evaluate the ethical results of their decisions and make ethical choices that subordinates emulate. Ethical leadership has been shown to be related to a variety of outcomes (see the meta - analysis by Bedi et al., 2016).

\section{PERCEIVED SUPPORT}

Organizational support theory involves the extent to which employees believe that the organization cares about them, provides favorable work conditions, and values their contributions (Eisenberger et al., 1986). The norm of reciprocity (Gouldner, 1960) and social exchange theory (Blau, 1964) are the basis for perceived support. According to Blau (1964), social exchange involves "the voluntary actions of individuals that are motivated by the returns they are expected to bring and typically do in fact bring from others" (p. 91). Employees exchange loyalty and effort for resources and benefits from the organization (Cropanzano and Mitchell, 2005). When employees believe the organization has treated them fairly (fair pay and promotional opportunities for their efforts), they will feel obligated to reciprocate that treatment (the norm of reciprocity) with increased loyalty and commitment (Eisenberger et al., 2001; Rhoades and Eisenberger, 2002). A high level of trust will develop between 
the parties, leading to long-term obligations (Rhoades and Eisenberger, 2002).

Most research has investigated the relationship between perceived organizational support (POS) and various employees' attitudes and behaviors (see the meta-analysis by Kurtessis et al., 2017). Perceived supervisor support (PSS) also is an important variable influencing employees' attitudes and behavior. PSS involves the degree to which employees believe their immediate supervisor cares about them and values their contribution (Eisenberger et al., 1986). Similar to POS, PSS has been linked to important outcomes (Rhoades and Eisenberger, 2002).

\section{THE RELATIONSHIP AMONG ETHICAL LEADERSHIP, DUTY ORIENTATION, AND PSS}

According to Hannah et al. (2014), duty orientation is a mental state formed by contextual factors, one of which is leadership. The ethical leader acting as a moral manager communicates to followers expected duties and responsibilities that contribute to the group's survival and performance. In addition, when followers believe that their leaders listen to what they say, have their best interests in mind rather than their own self-interests, and align reward systems with required behavior (traits of an ethical leader), followers will perceive leaders as displaying behavior that is consistent with group norms (Brown and Treviño, 2006). Because followers receive fair and caring treatment from an ethical leader, they will feel a moral obligation to reciprocate that behavior beyond what is expected of them (Brown et al., 2005). They will support team members (duty to members), expend additional effort to achieve the organization's mission (duty to mission), and behave in a moral manner while honoring the team's codes (duty to codes) (Eva et al., 2020). Via a social learning process, followers will emulate the leader's behavior and feel obligated to assist the group in the way exhibited by the leader thereby leading to increased duty obligation (Moss et al., 2020).

While no studies have analyzed the relationship between ethical leadership and duty orientation with a sample of salespeople, the limited research with other employees does indicate that ethical leadership is an antecedent to duty orientation. These studies have reported a significant relationship between ethical leadership and duty orientation (Eva et al., 2020; Hannah et al., 2014; Moss et al., 2020). Thus, the following hypothesis will be tested.

\section{Hypothesis 1: Ethical leadership is positively related to duty orientation.}

Interestingly, research has investigated outcomes of PSS but not antecedents of PSS. Three recent meta-analyses (Bedi et al., 2016; Hoch et al., 2018; Kurtessis et al., 2017) reported that POS was correlated significantly with various leadership theories (transformational, consideration, initiating structure, and leader-member exchange). These studies analyzed only POS and not PSS. In addition, the results indicated that no study has examined the relationship between perceived support and ethical leadership.

In organizations supervisors are vital regarding influencing subordinates' behavior (Eisenberger et al., 2002). In professional selling the role of the sales manager is especially important given the uniqueness and difficulties of a salesperson's job. The sales manager can increase salespersons' positive behavior through providing support to them. Research regarding PSS indicates that when employees perceive their supervisor cares about them, they will feel an obligation to reciprocate that treatment with positive work behaviors (Shanock and Eisenberger, 2006).

This situation is particularly relevant with respect to ethical leadership. Aspects of ethical leadership should be related to PSS within the sales force. Ethical leaders listen to their employees, are viewed as being trustworthy, and have their subordinates' best interests in mind (Brown et al., 2005). They are viewed as an appropriate source of information in the organization providing specific communication regarding expectations concerning ethical behavior. Salespeople will emulate the behavior of their 
sales manager when he or she treats them fairly and displays concern for their well-being (Brown et al., 2005).

No study could be found that analyzed the relationship between PSS and ethical leadership, although two studies reported a significant relationship between POS and ethical leadership (Eva et al., 2020; Loi et al., 2015). However, several traits of an ethical leader are like the characteristics of a supportive leader. Sales managers who are viewed as high in perceived support value salespersons' contribution to the organization, consider their goals and values, show concern for them, listen to their opinions, place followers' interests above their own interests, and care about their well-being (Brown et al., 2005). They treat the sales force with dignity by sincerely listening to their concerns and opinions and taking them into account when making decisions. Thus, sales managers who are ethical leaders also will be viewed by salespeople as being supportive of their efforts and serve as role models (Brown and Treviño, 2006).

Since both ethical leadership and perceived support are related to job attitudes and behaviors (Bedi et al., 2016; Kurtessis et al., 2017), a need exists to investigate the relationship between the two variables. Intuitively, sales managers who are viewed as ethical leaders should be perceived as being supportive by the sales force. Therefore, the following hypothesis will be tested.

Hypothesis 2: Ethical leadership is positively related to PSS.

Based on social exchange theory (Blau, 1964), duty orientation is proposed to be a mediator between PSS and performance outcomes. Salespeople who receive support from their sales manager (PSS) will have an increased responsibility to reciprocate that behavior toward both the organization and other team members (duty orientation) through enhanced intra-role performance and extra-role performance. Sales managers who show concern for their salespeople, care about their well-being, value their contributions, and are willing to help members of the salesforce when they have a problem will create a feeling of commitment from the salespeople toward achieving the organization's goals (Eisenberger et al., 2001).

An exchange relationship will develop when the salespeople believe they receive support from the sales manager (Eva et al., 2020). They will feel a moral obligation to return the favorable treatment provided by the sales manager through a higher sense of duty toward the organization, which will lead to increased organizational citizenship behavior and job performance. They will support and be committed to achieving the organization's mission, including making personal sacrifices to achieve the mission. They will feel obligated to mentor and support other team members. In a sales environment, salespeople who feel supported by the sales manager are willing to help new salespeople learn about products and assist with improving their selling skills with an emphasis on ethical behavior, which will lead to more sales.

Only one study has investigated the relationship between perceived support and duty orientation (Eva et al., 2020). In that study POS was reported to be an antecedent to duty orientation. PSS was not included. Theoretically, based on the norm of reciprocity (Gouldner, 1960) employees who receive support from their supervisor should feel a moral obligation to return that treatment with an increased duty to the organization. The supportive supervisor, acting as a moral agent of the organization and role model, will inspire followers to support their team members (duty to members), behave morally and honor the team's codes (duty to codes), and show a duty to mission by working harder (Hannah et al., 2014). The following hypothesis will be tested.

Hypothesis 3: PSS is positively related to duty orientation. 


\section{ANTECEDENTS OF ORGANIZATIONAL CITIZENSHIP BEHAVIORS AND JOB PERFORMANCE}

Organizational citizenship behavior and job performance are hypothesized to be outcomes of duty orientation. Organizational citizenship behavior appeared in the literature almost 40 years ago (Smith et al., 1983) and has been included in many studies (Podsakoff et al., 2014). Organ (1988) defined organizational citizen behaviors (OCBs) as "behavior(s) of a discretionary nature that are not part of the employee's formal role requirements, but nevertheless promote the effective functioning of the organization" (p. 4). In contrast, job performance refers to duties performed to fulfill the job requirements.

Only one study has investigated the relationship between duty orientation and in-role performance and extra-role performance (Eva et al., 2020). These authors reported that duty orientation was a predictor of both individual performance and OCBs. However, this study involved public sector Chinese employees. This study will be the first one to examine the relationship between duty orientation and job performance and OCBs with American employees. Based on social exchange theory (Blau, 1964) employees who perceive their supervisor supports them should feel a strong obligation to reciprocate that support through increased job performance and OCBs. Intuitively and empirically based on the results of the Eva et al. study (2020) duty orientation is hypothesized to be a predictor of job performance and OCBs.

Hypothesis 4a: Duty orientation is positively related to job performance.

Hypothesis $4 \mathrm{~b}$ : Duty orientation is positively related to OCBs.

Two recent meta-analyses (Bedi et al., 2016; Peng and Kim, 2020) indicated that ethical leadership had a significant correlation between OCBs and job performance. Therefore, ethical leadership is hypothesized to be a direct antecedent to both OCBs and job performance.

Hypothesis 5a: Ethical leadership is positively related to job performance.

Hypothesis 5b: Ethical leadership is positively related to OCBs.

One of the purposes of this study is to determine if the relationship between PSS and performance is direct or indirect through duty orientation. Only a few studies have examined the relationship between PSS and OCBs and performance (Bishop et al., 2020; DeConinck and Johnson, 2009; Talukder et al., 2018; Tremblay and Simard, 2018). However, within a sales environment, the sales manager is instrumental in providing support to the salespeople through coaching and training so they can be more productive. When salespeople are struggling, the sales manager provides encouragement and motivation. Based on the norm of reciprocity, when salespeople receive support from their sales manager, they will feel obligated to return the favor. PSS should be linked to OCB and job performance by the fact that a salesperson who receives support from his or her sales manager will feel a moral debt that encourages the desire for reciprocity in the form of organizational citizenship behavior and increased performance. Thus, PSS is hypothesized to be both indirectly related to intra-role performance and extra-role performance through duty orientation and a direct predictor of performance outcomes.

Hypothesis 6a: PSS is positively related to OCBs.

Hypothesis 6 b: PSS is positively related to performance. 


\section{RESEARCH METHODOLOGY}

Data were collected from a national firm in the computer industry as part of a larger study examining salesforce turnover. The researchers received permission from executives within the sales division to have sales personnel complete the confidential online survey. The salespeople completed all parts of the survey except for the two items related to job performance. A high percentage of both the sales managers $(45-88.2 \%)$ and salespeople $(203-76.8 \%)$ completed the survey. The average age of the salespeople was 34.8 , they had an average of 8.8 years of sales experience with the company, about 62 percent were male, and virtually all the salespeople were college graduates. The salesforce was compensated on a salary/commission basis. All but two of the sales managers had completed at least four years of college. They had been employed as a sales manager for an average of 9.2 years and managed an average of 5.1 salespeople. No statistical difference in demographics was found between the salespeople who completed a survey and those salespeople who did not.

\section{MEASURES}

The questionnaire appears in the Appendix. All items were measured using a five-point Likert scale (strongly disagree to strongly agree). Ethical Leadership was measured using the 10 - item scale developed by Brown et al. (2005). Perceived Supervisor Support was measured using four items from the survey of perceived organizational support (SPOS) developed by Eisenberger et al. (1986). Duty Orientation was measured using the 12-item scale developed by Hannah et al. (2014). Two items were used to measure Performance. The sales managers were asked to rate each salesperson's performance regarding achieving annual sales targets and keeping expenses at acceptable levels.

Organizational Citizenship Behavior was measured using the civic virtue and helping behavior scales developed by Podsakoff and MacKenzie (1994). Items for each of the two organizational citizenship behavior scales were merged into two parcels (helping behavior and civic virtue) in the interest of parsimony when testing the hypothesized model. Organ (1988) and Williams and Anderson (1991) identified two dimensions of OCB - OCBO involves the dimensions of sportsmanship, civic virtue, and compliance (direct benefit to the organization) and OCBI (direct benefit to the individual and indirect benefit to the organization) is comprised of dimensions such as altruism, helping, and courtesy. However, in the review of the literature Podsakoff et al. (2014) reported that no consistent method has been used to measure OCB. For example, they found that slightly more than half of the articles reviewed used a global or composite measure of OCB while only 17 percent used a latent variable method of analysis. Other studies have measured dimensions of OCB as proposed by Smith et al. (1983). In their meta-analysis LePine et al. (2002) advocated measuring OCB as a latent construct consisting of the two dimensions of $O C B I$ and $O C B O$. Thus, this study uses $O C B I$ and $O C B O$ as measures of organizational citizenship behavior.

\section{VALIDITY, RELIABILITY, AND FACTOR STRUCTURE}

The constructs meet the criteria recommended by Hair et al. (2018) for both validity and reliability. The standardized factor loadings for each construct exceeded the recommended level of .7: duty orientation .71 to .81; PSS .70 to .74; ethical leadership .71 to .83; OCB .72 to .76 , and performance .76 to .78 . The average variance extracted for the variables was above .50 (duty orientation .54, PSS .63, ethical leadership .65, performance .52, and OCB .51). All variance-extracted estimates are greater than the corresponding interconstruct squared correlations indicating discriminant validity. The construct reliability was as follows: duty orientation .88; PSS .86; ethical leadership .92; OCB .72, and performance .80 . 
The results of the multilevel confirmatory factor analysis (CFA) indicate a good fit (Hu and Bentler (1999) $(\chi 2=966.01, d f=804, p<.001, C F I=.96$, SRMR = .05; RMSEA = .03). In addition, a one factor test (Harman, 1976) was conducted as a test of common method bias. Results of this analysis support the proposed model via a significant change in chi square $(\Delta \chi 2=1824.34, \Delta d f=10 ; p<.001, \mathrm{CFI}=.85$; SRMR = .14; RMSEA = .11). As a more stringent test of model fit, a model of "next best fit" was also tested by loading performance and $O C B$ items onto a single latent variable. Results suggest that the proposed measurement model (modeling performance and OCBs as separate latent variables) provides superior fit $\left(\Delta \chi^{2}=13.71, \Delta d f=4 ; p<.001 ; \mathrm{CFI}=.96\right.$; SRMR $=.07$; RMSEA = .03). In sum, these results suggest that the proposed measurement model provides robust fit with the data.

Three steps were employed to eliminate the problem associated with common method bias (Podsakoff et. al., 2003). First, the survey items were dispersed randomly in the questionnaire. Second, both the salespeople and the sales managers completed parts of the questionnaire. The sales managers provided extra-role performance information while the salespeople completed the rest of the questionnaire. Finally, the results of the one factor test and the model of "next best fit" provide statistical evidence suggesting the absence of common method bias.

\section{RESULTS}

MPLUS was used to analyze the data utilizing a multilevel structural equation modeling (MSEM) technique. Multilevel estimation (multilevel maximum likelihood with robust standard errors) was needed since supervisors were rating more than one subordinate (thus violating the assumption in independence in maximum likelihood/OLS estimation). In addition, full information estimation was appropriate to assess the overall fit of the hypothesized model.

The correlation matrix, variable means, and standard deviations appear in Table 1.

Table 1. Correlations, Means, and Standard Deviations

\begin{tabular}{|c|c|c|c|c|c|c|}
\hline & 1 & 2 & 3 & 4 & 5 & 6 \\
\hline Duty & & & & & & \\
\hline Helping & $.17^{*}$ & & & & & \\
\hline Civic Virtue & $.16^{*}$ & $.38 * *$ & & & & \\
\hline Ethical Leader & $.40^{*}$ & $.35^{* *}$ & $.38 * *$ & & & \\
\hline Performance & $.22 * *$ & $.22^{* *}$ & $.14^{*}$ & $.30 * *$ & & \\
\hline PSS & $.33^{* *}$ & $.30 * *$ & $.29^{* *}$ & $.43^{* *}$ & $.18^{* *}$ & \\
\hline Means & 37.1 & 14.2 & 10.8 & 36.4 & 7.0 & 13.9 \\
\hline Std. Deviations & 9.6 & 2.5 & 6.7 & 6.6 & 1.7 & 2.7 \\
\hline
\end{tabular}

The results for the hypothesized structural model also indicated a good fit $(\chi 2=929.69, d f=796 ; p$ $<.05$; CFI = .97; SRMR = .05; RMSEA = .03). Six of the hypothesized relationships were supported. Ethical leadership is related positively to duty orientation $(\mathrm{H} 1, \beta=.314, p<.001)$; ethical leadership is related to positively to PSS $(\mathrm{H} 2, \beta=.503, p<.001)$; PSS is related positively to duty orientation $(\mathrm{H} 3, \beta=$ $.241, p<.05)$; duty orientation is related positively to job performance ( $\mathrm{H} 4 \mathrm{a}, \beta=.201, p<.05)$; ethical leadership was significantly related to OCBs ( $\mathrm{H} 5 \mathrm{~b}, \beta=.463, p<.001)$; and PSS is related positively to OCBs (H6a, $\beta=.321, p<.01)$. Duty orientation was not significantly related to OCBs $\left(H_{4} b, \beta=-.026, p=\right.$ $.845)$, ethical leadership was not significantly related to job performance ( $\left.\mathrm{H}_{5} \mathrm{a} \beta=.143, p=.099\right)$, and PSS was not related significantly to job performance (H6b, $\beta=.184, p=.143$ ). Subsequent Monte Carlo simulation results indicate a significant indirect effect of ethical leadership on OCBs as transmitted 
through PSS ( $\beta=.159, p<.05)$ and a significant indirect effect of ethical leadership on performance as transmitted through duty orientation $(\beta=.114, p<.05)$. Full results of this analysis are displayed visually in Figure 1.

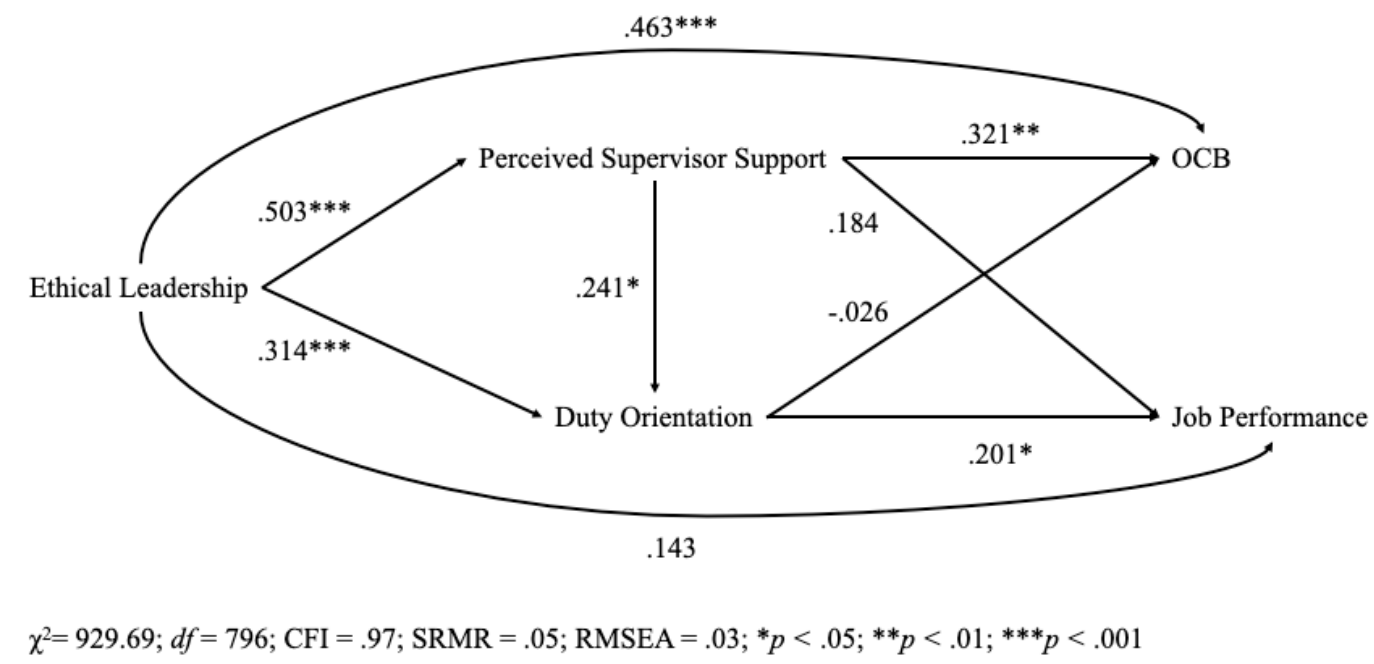

Figure 1. Final Model

\section{CONCLUSION}

\section{THEORETICAL IMPLICATIONS}

The purpose of this study was to examine the relationship among ethical leadership, duty orientation, PSS, and employee performance outcome variables. Prior research has shown that ethical leadership is related to a variety of job attitudes and outcomes (Bedi et al., 2016). The results extend prior research (Eva et al., 2020) investigating outcomes of ethical leadership by showing the role of duty orientation and PSS as mediators between ethical leadership and job performance and OCBs with a sample of salespeople and sales managers.

The first theoretical implication is that duty orientation mediates the relationship between ethical leadership and performance outcomes. Based on social exchange theory (Blau, 1964), when ethical leaders listen to what subordinates say, have their best interests in mind, are trustworthy, and use rewards and punishment to influence ethical behavior, salespeople report they have a greater duty to support the organization's mission and goals and help other salespeople in their work unit while behaving honorably. The important theoretical implication is that indirectly through duty orientation salespeople will perform at a higher level when their sales manager is viewed by the salesforce as being an ethical leader.

Second, this study has an important theoretical implication regarding PSS. Most research examines the influence of POS on various employee attitudes and behaviors. However, the support of the sales manager (PSS) is especially important in helping salespeople achieve quota (MacKenzie et al., 2001; Peesker et al., 2019). This study is the first one to include PSS in a model testing the relationship among duty orientation, ethical leadership, and performance outcomes. The important theoretical implication regarding PSS is its role as a mediator between ethical leadership and duty orientation. Based on social exchange theory (Blau, 1964) and the norm of reciprocity (Gouldner, 1960), an important theoretical implication is that salespeople who perceive support from their sales manager will reciprocate that behavior through increased duty orientation, which leads to increased effort and performance. While 
prior research has found support for ethical leadership influencing POS (Eva et al., 2020; Loi et al. 2015; Wang et al. 2019), this study's results indicate that ethical leadership also affects PSS.

Third, these results provide a more accurate view of how ethical leadership, PSS, and duty orientation influence job performance and OCBs. Notably, PSS and duty orientation are both key factors as PSS was the sole mediator of the ethical leadership-OCB relationship and duty orientation was the sole mediator of the ethical leadership-performance relationship.

Both ethical leadership and PSS were significantly related to OCBs. Practicing ethical leadership does influence salespersons' willingness to engage in OCBs, which supports prior research (Bedi et al., 2016; Peng and Kim, 2020). The sales manager who is viewed as an ethical leader influences salespeople to go beyond their normal duties including helping other salespeople and attending functions that help the company's image. Perceived support from the sales manager also encourages salespeople to engage in OCBs. When salespeople view their sales manager as someone who cares about their well-being and values their contributions, they are willing to be involved in OCBs.

Fourth, only one variable, duty orientation, was directly related to job performance. The reason for the insignificant results cannot be determined. However, one reason for the lack of a significant result between ethical leadership, duty orientation, and PSS and performance could be due to using performance data provided by the sales managers from one company rather than simply asking for salespeople to report their performance. Using self-reported performance data has questionable validity (Jaramillo et al., 2003). Thus, the results of this study could be viewed as a more valid assessment of the relationship between ethical leadership, PSS, duty orientation and job performance. Future research needs to survey salespeople from multiple organizations to confirm these results.

\section{PRACTICAL IMPLICATIONS}

The results of this study have several practical implications for sales organizations. First, ethical leadership is very important. Sales managers are responsible for meeting sales expectations for their district. When a sales manager is viewed as an ethical leader who disciplines employees for violating ethical standards, defines success not just by results but also by the way that they are obtained, and discusses business ethics or values with his or her salespeople, salespersons' duty orientation is being influenced. Salespeople who rank high on duty orientation do what is right, act honorably, support the organization, and work to ensure the organization's goals succeed. Thus, increasing the sense of duty is important. How can sales organizations increase salespersons' level of duty orientation? One suggestion has been to have the employees participate in reflection exercises (Moss et al., 2020) where the salespeople reflect on how their behavior impacts stakeholders and coworkers. Clearly, more work needs to be done to understand the reasons that some salespeople feel a greater sense of duty orientation than other salespeople.

Organizations need to ensure that their salespeople perceive they are receiving adequate support from their sales manager (PSS). Salespeople report higher duty orientation when their sales manager values their contribution, appreciates their efforts, provides help when they have a problem, and cares about their well-being. Senior management needs to ask salespeople if they are receiving adequate support from their sales manager. If not, managers must glean information regarding further needed support so they can perform their jobs better. This situation is important because when salespeople are supported by their sales manager, they report a high level of duty orientation, which leads to increased job performance.

Given the importance of ethical leadership in this study and other studies (Bedi et al., 2016), organizations need to hire and/or develop sales managers who possess the traits of ethical leadership. Often organizations promote top performing salespeople to sales management positions. However, some of these salespeople may not have the traits of an ethical leader. Perhaps the best place to start 
is with human resources. First, selection methods should be implemented emphasizing the traits of ethical leadership as part of the hiring/promotion process. Second, training needs to stress the importance of ethical leadership and behaviors that the sales managers should use to implement appropriate ethical behavior among the sales force.

\section{LIMITATIONS AND FUTURE RESEARCH}

Several limitations need to be mentioned. First, this study was one of the first to investigate the relationship among ethical leadership, duty orientation, PSS, intra-role performance and extra-role performance within a sales organization. Future research needs to replicate these results with other types of employees and organizations since the nature of a salesperson's job (boundary spanning role, quota, and incentive compensation) may make these results unique to salespeople. Second, the study has limited generalizability as the sample is only from one organization. Analyzing salespeople from different industries or with different compensation plans may produce different results. Third, since the study was cross-sectional, causality is not supported. Experimental or longitudinal study designs should be considered for future research. Fourth, future research could examine the relationship between duty orientation and other leadership theories such as leader-member exchange, servant leadership, and transformational leadership. Fifth, this study examined only two outcome variables, job performance and organizational citizenship behaviors. Future studies could investigate the relationship between duty orientation and turnover intentions and actual turnover.

In conclusion this study has shown the importance of duty orientation as a mediator between ethical leadership and outcome variables. The study also has shown the importance of including PSS in studies analyzing outcomes of ethical leadership. Unfortunately, business scandals continue to occur and conducting research into outcomes of ethical leadership continues to be important. This study has initiated new areas of research into understanding the outcomes of ethical leadership in the salesforce. 


\section{REFERENCES}

Babin, B. J., Boles, J. S., \& Robin, D. P. (2000). Representing the perceived ethical work climate among marketing employees. Journal of the Academy of Marketing Science, 28(3), 345-358.

Bandura, A. (1977). Social Learning Theory. New York: General Learning Press.

Bandura, A. (1986). Social foundations of thought and action: A social cognitive theory, PrenticeHall, Englewood Cliffs, NJ.

Bedi, A., Alpaslan, C. M., \& Green, S. A. (2016). A meta-analytic review of ethical leadership outcomes and moderators. Journal of Business Ethics, 139(3), 517-536.

Bishop, J. W., Prabagaran, N., \& Daily, B. F. (2020). Employee support and their perceptions of quality and environmental performance: The role of citizenship behavior. Journal of Managerial Issues, 32(4), 421-439.

Blau, P. M. (1964), Exchange and Power in Social Life, New York: Wiley

Blocker, C. P., Cannon, J. P., Panagopoulos, N. G., \& Sager, J. K. (2012). The role of the sales force in value creation and appropriation: New directions for Research. Journal of Personal Selling \& Sales Management, 32(1), 15-28.

Boichuk, J. P., Bolander, W., Hall, Z. R., Ahearne, M., Zahn, W. J., \& Nieves, M. (2014). Learned helplessness among newly hired salespeople and the influence of leadership. Journal of Marketing, 78(1), 95-111.

Brown, M. E. \& Mitchell, M. S. (2010). Ethical and unethical leadership: Exploring new avenues for future research. Business Ethics Quarterly 20(4), 583-616.

Brown, M. E., \& Treviño, L. K. (2006). Ethical leadership: A review and future directions. Leadership Quarterly, 17(6), 595-616.

Brown, M. E., Treviño, L. K., \& Harrison, D. A. (2005). Ethical leadership: A social learning perspective for construct development and testing. Organizational Behavior and Human Decision Processes, 97(2), 117-134.

Cropanzano, R., \& Mitchell, M. S. (2005). Social exchange theory: An interdisciplinary review. Journal of Management, 31, 874-900

DeConinck, J. B. (2015). Outcomes of ethical leadership among salespeople. Journal of Business Research, 68(5), 1086-1093.

DeConinck, J. B. \& Johnson, J. T. (2009). The effects of perceived supervisor support, perceived organizational support, and organizational justice on turnover among salespeople. Journal of Personal Selling \& Sales Management, 29(4), 333-350.

Detert, J. R., Treviño, L. K., Burris, E. R., \& Andiappan, M. (2007). Managerial modes of influence and counterproductivity in organizations: A longitudinal business-unit-level investigation. Journal of Applied Psychology, 92 (4), 993-1005.

Eisenberger, R., Armeli, S., Rexwinkel, B., Lynch, P. D., \& Rhoades, L. (2001). Reciprocation of perceived organizational support. Journal of Applied Psychology, 86(1), 42-51.

Eisenberger, R., Huntington, R., Hutchison, S. \& Sowa, D. (1986). Perceived organizational Support. Journal of Applied Psychology, 71(3), 500-507.

Eisenberger, R., Stinglhamer, F., Vandenberghe, C., Sucharski, I. L., Rhoades, L., \& Stinglhamber, F. (2002). Perceived supervisor support: contributions to perceived organizational support and employee retention. Journal of Applied Psychology, 87(3), 565-573.

Eva, N., Newman, A., Miao, Q., Wang, D., \& Cooper, B. (2020). Antecedents of duty orientation and follower work behavior: The interactive effects of perceived organizational support and ethical leadership. Journal of Business Ethics, 161(3), 627-639.

Gouldner, A. W. (1960). The norm of reciprocity: A preliminary statement. American Sociological Review, 25(2), 161-178. 
Grant, A. M., \& Wrzesniewski, A. (2010). I won't let you down ... or will I? Core self-evaluations, otherorientation, anticipated guilt and gratitude, and job performance. Journal of Applied Psychology, 95(1), $108-121$.

Hair, J. F., Babin, B. J., Anderson, R. E., \& Black, W. C. (2018). Multivariate Data Analysis $8^{\text {th }}$ ed. India: Cengage.

Hannah, S. T., Jennings, P. L., Bluhm, D., Peng, A.C., \& Schaubroeck, J. M. (2014). Duty orientation: Theoretical development and preliminary construct testing. Organizational Behavior \& Human Decision Processes. 123(2), 220-238.

Harman, H. H. (1976), Modern Factor Analysis, (3rd ed.), The University of Chicago Press, Chicago, IL

Hoch, J. E., Bommer, W. H., Dulebohn, J. H., \& Wu, D. (2018). Do ethical, authentic, and servant leadership explain variance above and beyond transformational leadership? A meta-analysis. Journal of Management, 44(2), 501-529.

Hu, L., \& Bentler, P. M. (1999). Cutoff Criteria for fit indexes in covariance structure analysis: Conventional criteria versus new alternatives. Structural Equation Modeling 6, 1-55.

Ingram, T. N., LaForge, R. W., \& Schwepker, C. H. (2007). Salesperson ethical decision making: The impact of sale leadership and sales management control strategy. Journal of Personal Selling \& Sales Management, 27(4), 301-315.

Jaramillo, F., Carrillat, F. A. \& Locander, L. B. (2003). Starting to solve the method puzzle in salesperson self-report evaluations," Journal of Personal Selling \& Sales Management, 23(4), 369-377.

Kurtessis, J. N., Eisenberger, R., Ford, M. T., Buffardi, L. C., Stewart, K. A., \& Adis, C. S. (2017). Perceived organizational support: A meta-analytic evaluation of organizational support theory. Journal of Management, 43(6), 1854-1884.

LePine, J. A., Erez, A., \& Johnson, D. E. (2002). The nature and dimensionality of organizational citizenship behavior. Journal of Applied Psychology, 87(1), 52-65.

Loi, R., Lam, Long W., Ngo, H. Y., \& Cheong, S. (2015). Exchange mechanisms between ethical leadership and affective commitment, Journal of Managerial Psychology, 30(6), 645-658.

MacKenzie, S. B., Podsakoff, P. M., \& Rich, G. A. (2001). Transformational and transactional leadership and salesperson performance. Journal of the Academy of Marketing Science, 29(2), 115-134.

Moon, $\mathrm{H}$. (2001). The two faces of conscientiousness: Duty and achievement striving in escalation of commitment dilemmas. Journal of Applied Psychology, 86(3), 533-540.

Moon, H., Kamdar, D., Mayer, D. M., \& Takeuchi, R. (2008). Me or we? The role of personality and justice as other-centered antecedents to innovative citizenship behaviors within organizations. Journal of Applied Psychology, 93(1), 84 -94.

Moss, S. E., Song, M., Hannah, S. T., Wang, Z., \& Sumanth, J. J. (2020). The duty to improve oneself: How duty orientation mediates the relationship between ethical leadership and followers' feedback-seeking-avoiding behavior. Journal of Business Ethics, 165(4), 615-631.

Ng, T. W. H., \& Feldman, D. C. (2015). Ethical leadership: Meta-analytic evidence of criterion-related and incremental validity. Journal of Applied Psychology, 100(3), 948-965.

Organ, D. W. (1988). Organizational citizenship behavior: The good soldier syndrome. Lexington, MA: Lexington Books.

Peesker, K. M., Ryals, L. J., Rich, G. A., \& Boehnke, S. E. (2019). A qualitative study of leader behaviors perceived to enable salesperson performance. Journal of Personal Selling and Sales Management, 39(4), 319-333.

Peng, A. C. \& Kim, D. (2020). A meta-analytic test of the differential pathways linking ethical leadership to normative conduct. Journal of Organizational Behavior, 41(4), 348368.

Podsakoff, P. M. \& MacKenzie, S. B. (1994). Organizational sales unit effectiveness. Journal of Marketing Research, 31(3), 351-363. 
Podsakoff, P. M., MacKenzie, S. B., Lee, J. Y., \& Podsakoff, N. P. (2003). Common biases in behavioral research: A critical review of the literature and recommended remedies. Journal of Applied Psychology, 88(5), 879-903.

Podsakoff, N. P., Podsakoff, P. M., Mackenzie, S, B., Maynes, T. D., \& Spoelma, T. M. (2014). Consequences of unit-level organizational citizenship behaviors: A review and recommendations for future research. Journal of Organizational Behavior 35, 87-119.

Rhoades, L. \& Eisenberger, R. (2002). Perceived organizational support: A review of the literature. Journal of Applied Psychology, 87(4), 698-714.

Schwepker, C. H. \& Ingram, T. N. (2016). Ethical leadership in the salesforce: effects on salesperson customer orientation, commitment to customer value and job stress. Journal of Business \& Industrial Marketing, 31(7), 914-927.

Shanock, L. R., \& Eisenberger, R. (2006). When supervisors feel supported: Relationships with subordinates' perceived supervisor support, perceived organizational support, and performance. Journal of Applied Psychology, 91(3), 689-695.

Smith, C. A., Organ, D. W., \& Near, J. P. (1983). Organizational citizenship behavior: Its nature and antecedents. Journal of Applied Psychology 68(4), 655- 663.

Talukder, A., Vickers, M. \& Khan, A. (2018). Supervisor support and work-life balance: impacts on job performance in the Australian financial sector. Personnel Review, 47(3), 727-744.

Tremblay, M., \& Simard, G. (2018). A multifocal approach to study social support and job performance: A target similarity consideration of development-enhancing practices, leadership, and structure. Journal of Business Research, 92, 118-130.

Trevino, L. K., Hartman, L. P., \& Brown, M. (2000). Moral person and moral manager: How executives develop a reputation for ethical leadership. California Management Review, 42(4), 128-142.

Wang, Z., \& Xu, H. (2019). When and for whom ethical leadership is more effective in eliciting work meaningfulness and positive attitudes: The moderating roles of core self-evaluation and perceived organizational support. Journal of Business Ethics, 156(4), 919-940.

Williams, L. J., \& Anderson, S. E. (1991). Job satisfaction and organizational commitment as predictors of organizational citizenship and in-role behaviors. Journal of Management, 17, 601- 617. 


\section{APPENDIX}

\section{DUTY ORIENTATION}

I put the interests of my team ahead of my personal interests

I do all that I can to support the organization

I am faithful to my team members

I am loyal to my leaders and team

I accept personal risk or loss in support of the mission/organization goals

I make personal sacrifices to serve the mission/organization goals

I do whatever it takes to not let the mission/organization goals fail

I get the job done under the toughest conditions

I do what is right always

I demonstrate personal integrity when challenged

I will not accept dishonor

I set the example for honorable behavior for others

\section{ORGANIZATIONAL CITIZENSHIP BEHAVIOR HELPING BEHAVIOR}

I give my time to help other salespeople who have work-related problems.

I take time out of busy schedule to help with recruiting or training new salespeople.

I encourage other salespeople who are down.

I take steps to prevent problems with other salespeople.

\section{ORGANIZATIONAL CITIZENSHIP BEHAVIOR CIVIC VIRTUE}

I attend functions that are not required but help my company's image.

I attend training/information sessions that salespeople are encouraged but not required to attend.

I attend and actively participate in sales meetings.

\section{ETHICAL LEADERSHIP}

My sales manager disciplines employees who violate ethical standards

My sales manager conducts his/her personal life in an ethical manger.

My sales manager has the best interests of employees in mind.

My sales manager makes fair and balanced decisions.

My sales manager can be trusted.

My sales manager discussed ethics or values with employees.

My sales manager sets an example of how to do things the right way in terms of ethics.

My sales manager discusses business ethics or values with employees.

My sales manager defines success not just by results but also the way that they are obtained.

My sales manager, when making decisions, asks "what is the right thing to do."

\section{PERCEIVED SUPERVISOR SUPPORT}

My sales manager values my contribution.

My sales manager strongly considers my goals and values.

Help is available from my supervisor when I have a problem.

My sales manager cares about my opinions. 